\title{
Influence of Temperature on the Water Relations of Polypaecilum pisce and Basipetospora halophila, Two Halophilic Fungi
}

\author{
By KATHRYN A. WHEELER, * AILSA D. HOCKING AND J. I. PITT \\ CSIRO Division of Food Processing, PO Box 52, North Ryde, NSW 2113, Australia
}

(Received 4 January 1988; revised 9 March 1988)

\begin{abstract}
Growth characteristics of Polypaecilum pisce and Basipetospora halophila, two fungi isolated from dried salt fish, were examined at $20,30,34$ and $37^{\circ} \mathrm{C}$ over a range of water activity $\left(a_{\mathrm{W}}\right)$ values $(0.99-0.70)$ on media containing various concentrations of $\mathrm{NaCl}$ or glucose/fructose. At high $a_{\mathrm{W}}$ growth of $P$. pisce was similar on media containing either solute, but below $0.90 a_{\mathrm{W}}$ growth was more rapid on $\mathrm{NaCl}$ media, indicating that $P$. pisce can be classified as a halophilic fungus. The minimum $a_{\mathrm{w}}$ for growth on $\mathrm{NaCl}$-based media was 0.746 ; on glucose/fructose media the minimum was $0.700 a_{\mathrm{w}}$. Optimal growth, i.e. growth at $80 \%$ or more of the maximum growth, occurred between 0.96 and $0.91 a_{\mathrm{w}}$ at $30^{\circ} \mathrm{C}$. Over the wide range of temperatures studied, $B$. halophila exhibited more rapid growth on $\mathrm{NaCl}$ media than on glucose/fructose media over the entire range of $a_{\mathrm{W}}$ at which growth occurred. The optimal growth rate on $\mathrm{NaCl}$ based media occurred between 0.89 and $0.86 a_{\mathrm{w}}$, an exceptionally low value. $B$. halophila can be classified as an extreme halophile, markedly intolerant of high $a_{\mathrm{w}}$, particularly on glucose/fructose-based media at temperatures above $30^{\circ} \mathrm{C}$.
\end{abstract}

\section{INTRODUCTION}

During a study of fungal spoilage of dried fish from Indonesia, several interesting fungi were encountered. The most prevalent fungus was a previously undescribed species, now named Polypaecilum pisce (Pitt \& Hocking, 1985), which was isolated from $42 \%$ of the fish examined, in extreme cases appearing as conspicuous white growth over large areas of the fish surface (Wheeler et al., 1986). Studies of growth at $25^{\circ} \mathrm{C}$ in this laboratory indicated that it was a salttolerant xerophile (Andrews \& Pitt, 1987). Basipetospora halophila (van Beyma) Pitt and Hocking (Pitt \& Hocking, 1985) was isolated much less frequently from the fish, but preliminary studies (Andrews \& Pitt, 1987) indicated that it grew at very low water activities $\left(a_{\mathrm{W}}\right)$ and that growth was stimulated by $\mathrm{NaCl}$, although there was no obligate requirement. This paper describes further studies of the water relations of these fungi over a range of temperatures.

\section{METHODS}

Fungi. The isolates studied were Polypaecilum pisce FRR 2733 and Basipetospora halophila FRR 2787. FRR denotes the culture collection of the CSIRO Division of Food Processing, North Ryde, NSW 21 13, Australia. Only one isolate of each species was studied. Andrews \& Pitt (1987) have shown that the behaviour of different isolates of $\boldsymbol{B}$. halophila was very similar.

Media. Media of various $a_{\mathrm{W}}$ values were prepared by adding $\mathrm{NaCl}$ or a mixture of equal weights of glucose and fructose to a basal medium containing $1 \%(\mathrm{w} / \mathrm{v})$ malt extract, $1 \%(\mathrm{w} / \mathrm{v})$ yeast extract, $0.1 \%$ dipotassium hydrogen phosphate and $2 \%(\mathrm{w} / \mathrm{v})$ agar. Media with $a_{\mathrm{w}}$ values above 0.92 were sterilized by steaming for $15 \mathrm{~min}$ on three successive days, the remainder by a single 15 min steam treatment (Andrews \& Pitt, 1987). Nominal $a_{\mathrm{w}}$ values of 0.99-0.70 were used in preparation of the media. The appropriate concentrations of controlling solutes were calculated using the data of Robinson \& Stokes (1955) for media containing $\mathrm{NaCl}$, and of Norrish (1966) for glucose/fructose media. Actual $a_{\mathrm{W}}$ values were determined with the Sina-scope instrument (Sina, Zurich, Switzerland). 
Cultivation and examination. Inoculation of the fungi and observation of germination and growth were done as described by Pitt \& Hocking (1977). Cultures were grown on Millipore Petri Slides containing approximately $2 \mathrm{ml}$ medium. Inoculation was done by placing a needle point of mature spores at the centre of the slide. Incubation was for a maximum of $100 \mathrm{~d}$ at $20,30,34$ and $37^{\circ} \mathrm{C}$. The Petri slides were examined regularly using a transmitted light microscope.

\section{RESULTS}

\section{Germination}

The minimum $a_{\mathrm{W}}$ values for germination are given in Table 1.P. pisce was least tolerant of low $a_{\mathrm{W}}$ at $20^{\circ} \mathrm{C}$, with germination not occurring below $0.799 a_{\mathrm{W}}$. At all temperatures, $P$. pisce germinated at lower $a_{\mathrm{W}}$ values on glucose/fructose media than on $\mathrm{NaCl}$-based media (Table 1). However at $30^{\circ} \mathrm{C}$, i.e. close to its optimum temperature, $P$. pisce germinated on media containing saturated $\mathrm{NaCl}$.

Germination of $B$. halophila occurred on the media containing saturated $\mathrm{NaCl}(0.750-0.746$ $\left.a_{\mathrm{w}}\right)$ at $20,25,30$ and $34^{\circ} \mathrm{C}$, with most rapid germination occurring at $30^{\circ} \mathrm{C}$. At $37^{\circ} \mathrm{C}$ the lowest $a_{\mathrm{W}}$ for germination was 0.770 on $\mathrm{NaCl}$ media (Table 1).

Representative data for germination times of $P$. pisce are shown in Fig. 1, in which log reciprocal germination time is plotted against $a_{\mathrm{w}}$. Data are shown only for $30^{\circ} \mathrm{C}$, the temperature at which germination was most rapid, and for $20^{\circ} \mathrm{C}$, where germination was prolonged. Germination times at 34 and $37^{\circ} \mathrm{C}$ were similar to, but slightly longer than, those at $30^{\circ} \mathrm{C}$. P p pisce was most tolerant of high concentrations of $\mathrm{NaCl}$ at $30^{\circ} \mathrm{C}$. Above $0.87 a_{\mathrm{W}}$ germination at all temperatures occurred faster on media containing $\mathrm{NaCl}$ than glucose/fructose.

Germination data for B. halophila at three temperatures, 20,30 and $37^{\circ} \mathrm{C}$ are shown in Fig. 2. Germination times were shortest on media containing $\mathrm{NaCl}$ as the $a_{\mathrm{W}}$-controlling solute. Temperature did not markedly affect germination except at $37^{\circ} \mathrm{C}$ where germination on glucose/fructose medium was restricted to $a_{\mathrm{W}}$ values between 0.928 and 0.876 , while germination on $\mathrm{NaCl}$-based media occurred between 0.943 and $0.770 a_{\mathrm{W}}$.

At all temperatures examined $P$. pisce germinated at the highest $a_{\mathrm{W}}$ tested (0.998), while $B$. halophila failed to germinate above $0.963 a_{\mathrm{W}}$ at $34{ }^{\circ} \mathrm{C}$ and $0.943 a_{\mathrm{W}}$ at $37^{\circ} \mathrm{C}$.

\section{Growth rates}

Radial growth rates of $P$. pisce and $B$. halophila are shown in Figs 3 and 4, respectively. In general the effects of temperature and solute on growth were similar to those on germination.

As growth temperature was raised from 20 to $37^{\circ} \mathrm{C}$, the optimal $a_{\mathrm{W}}$ for growth of $P$. pisce shifted, from 0.95 or higher at 20 and $25^{\circ} \mathrm{C}$ to $0.92-0.94$ at $37^{\circ} \mathrm{C}$. Growth of $P$. pisce at 30,34 and $37^{\circ} \mathrm{C}$ was considerably faster than at 20 and $25^{\circ} \mathrm{C}$. $P$. pisce grew most rapidly at $30^{\circ} \mathrm{C}$, where, at optimal $a_{\mathrm{W}}$, growth was two to three times faster than at $20^{\circ} \mathrm{C}$. Also, at $30^{\circ} \mathrm{C} P$. pisce grew at the lowest $a_{\mathrm{W}}$ tested for both media.

At most $a_{\mathrm{W}}$ values growth of $P$. pisce was favoured by the addition of $\mathrm{NaCl}$ to the medium. It was notable that at $a_{\mathrm{W}}$ values below the optima, particularly below $0.90 a_{\mathrm{W}}, P$. pisce grew more rapidly on $\mathrm{NaCl}$ than on glucose/fructose media (Fig. 3). For example, at 30 and $34^{\circ} \mathrm{C}$ and 0.80 $a_{\mathrm{w}}$ growth rates on $\mathrm{NaCl}$ were nearly three times higher than those on the glucose/fructose media. This marked difference was still apparent at $a_{\mathrm{W}}$ values below $0 \cdot 80$. Growth above $0.90 a_{\mathrm{W}}$ was less affected by solute or temperature, except at $20^{\circ} \mathrm{C}$ where growth on glucose/fructose was more rapid than on $\mathrm{NaCl}$ media between 0.98 and $0.92 a_{\mathrm{W}}$.

B. halophila exhibited more rapid growth on $\mathrm{NaCl}$ media over the whole range of $a_{\mathrm{W}}$ at which growth occurred (Fig. $4 a$ ). Optimal growth, that is growth at $80 \%$ or more of the maximum growth recorded at a particular temperature, occurred at very low $a_{\mathrm{W}}$ values, between 0.93 and 0.86 on $\mathrm{NaCl}$-based media and 0.93 and 0.91 on glucose/fructose media. Water activity for optimal growth of $B$. halophila at $20^{\circ} \mathrm{C}$ was little affected by solute. However, at 25,30 and $37^{\circ} \mathrm{C}$ optimal growth was solute dependent. $B$. halophila achieved optimal growth at a considerably lower $a_{\mathrm{W}}$ on $\mathrm{NaCl}$ media than on glucose/fructose media at 25,30 and $37^{\circ} \mathrm{C}$. At $34^{\circ} \mathrm{C}$ the effect of solute was not as marked but optimal growth was still achieved at a lower $a_{\mathrm{W}}$ on NaCl-based media. 


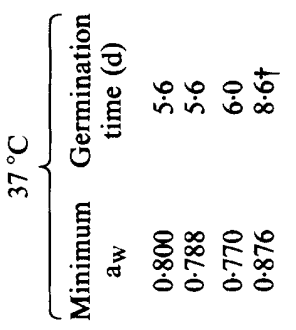

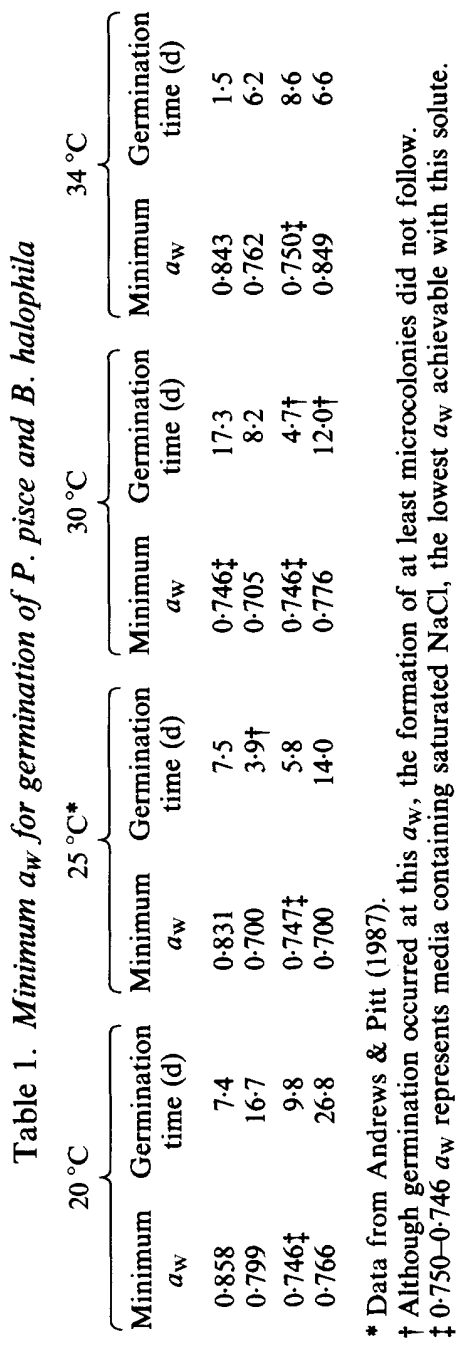

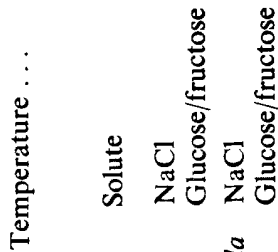

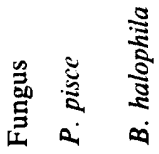




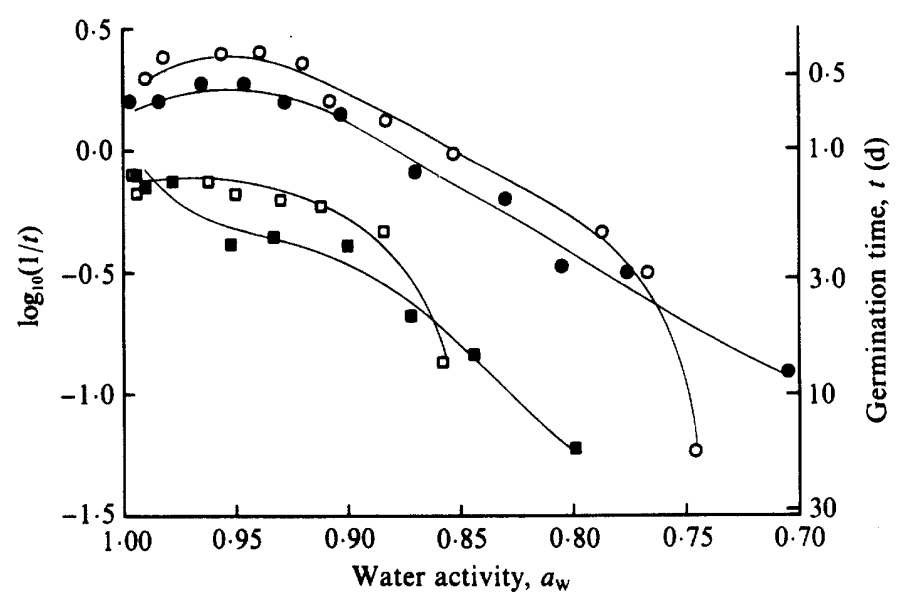

Fig. 1. Effect of temperature and solute on the time taken $(t)$ in days for germination of P. pisce. $\square, \square$, $20^{\circ} \mathrm{C} ; 0, \mathrm{O}, 30^{\circ} \mathrm{C} ; \mathbf{\square}, \boldsymbol{O}$, glucose/fructose; $\square, \mathrm{O}, \mathrm{NaCl}$.

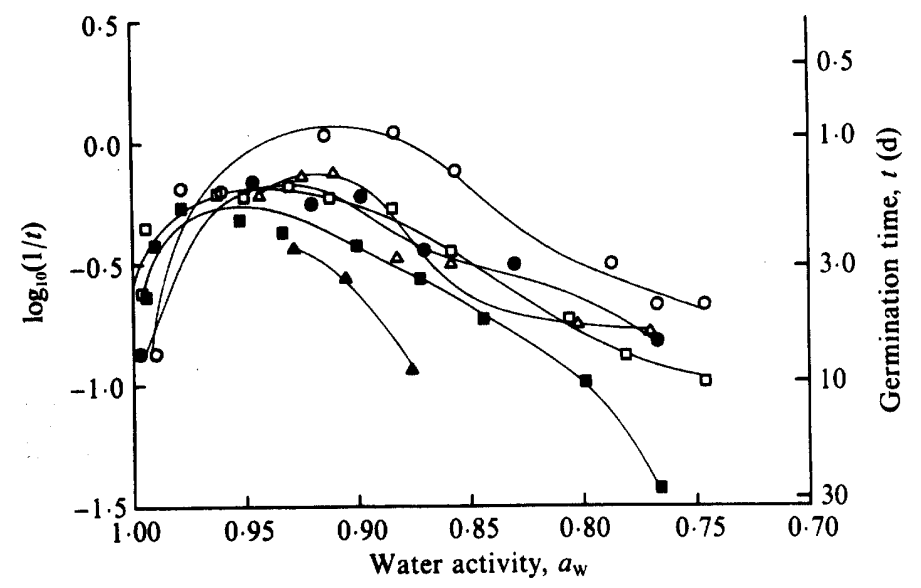

Fig. 2. Effect of temperature and solute on the time taken $(t)$ in days for germination of $B$. halophila. $\square$, $\square, 20^{\circ} \mathrm{C} ; \bullet, O, 30^{\circ} \mathrm{C} ; \Delta, \triangle, 37^{\circ} \mathrm{C} ; \square, \bullet, \Delta$, glucose/fructose; $\square, O, \triangle, \mathrm{NaCl}$.

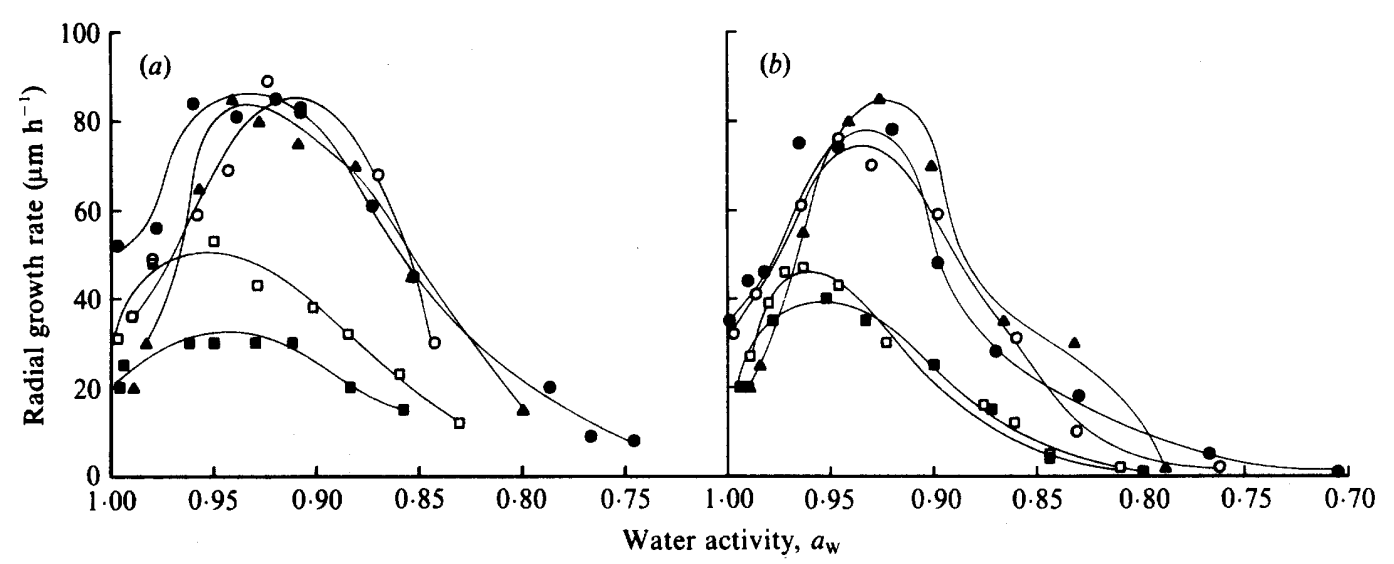

Fig. 3. Effect of temperature on the radial growth rate of $P$. pisce. $(a) \mathrm{NaCl}$; (b) glucose/fructose. $20^{\circ} \mathrm{C} ; \square, 25^{\circ} \mathrm{C} ; 0,30^{\circ} \mathrm{C} ; 0,34^{\circ} \mathrm{C} ; \triangle, 37^{\circ} \mathrm{C}$. 


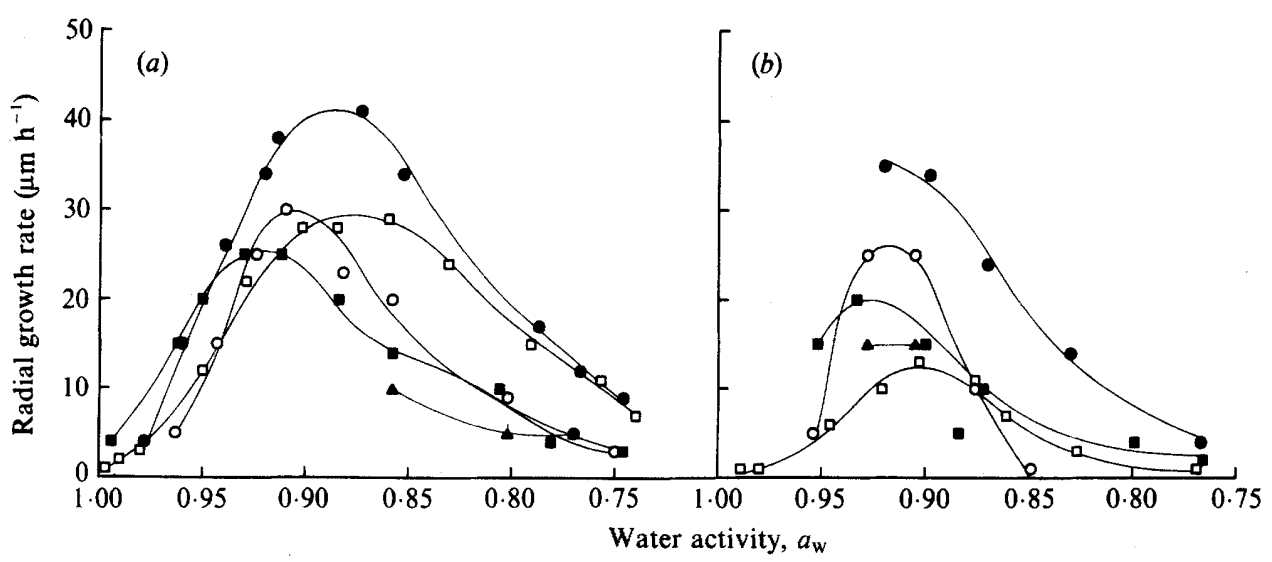

Fig. 4. Effect of temperature on the radial growth rate of $B$. halophila. (a) $\mathrm{NaCl} ;(b)$ glucose/fructose. $\square, 20^{\circ} \mathrm{C} ; \square, 25^{\circ} \mathrm{C} ; 0,30^{\circ} \mathrm{C} ; 0,34^{\circ} \mathrm{C} ; \Delta, 37^{\circ} \mathrm{C}$.

At $30{ }^{\circ} \mathrm{C}$ on $\mathrm{NaCl}$ media optimal growth was achieved between 0.91 and $0.87 a_{\mathrm{W}}$ (Fig. $4 a$ ). At $0.87 a_{\mathrm{w}}$ growth was $40-50 \%$ faster on $\mathrm{NaCl}$ than on glucose/fructose. The most notable effect of temperature increase above $30^{\circ} \mathrm{C}$ was a rapid decrease in growth rate below optimum $a_{\mathrm{W}}$. At $0.87 a_{\mathrm{w}}$ an increase of temperature from 30 to $34{ }^{\circ} \mathrm{C}$ resulted in a $30-40 \%$ decrease in the rate of growth of $B$. halophila. At $37^{\circ} \mathrm{C}$ growth on $\mathrm{NaCl}$ at $0.86 a_{\mathrm{W}}$ was only $28 \%$ of that at $30^{\circ} \mathrm{C}$.

$B$. halophila was markedly intolerant of high $a_{\mathrm{w}}$, especially on glucose/fructose-based media. Growth was very slow at or above $0.95 a_{\mathrm{W}}$. As temperature increased tolerance of high $a_{\mathrm{W}}$ decreased considerably. The maximum $a_{\mathrm{W}}$ for growth on $\mathrm{NaCl}$ at $20^{\circ} \mathrm{C}$ was 0.994 while at $37^{\circ} \mathrm{C}$ it was only $0 \cdot 858$.

In general the minimum $a_{\mathrm{w}}$ required for growth of both species was the same as that required for germination. In only a few cases where germination times were long, growth did not occur within the duration of the experiment. This was not the case for $B$. halophila at high $a_{\mathrm{W}}$ : the maximum $a_{\mathrm{W}}$ at which germination occurred was always greater than that at which growth occurred.

\section{DISCUSSION}

In recent years the term halophile has been applied only to specialized bacteria. Pitt (1975) reported that at that time there were no known halophilic fungi: fungi reported to be halophilic, such as Wallemia sebi, had been shown to grow at least as well in glucose-based media as in saltbased media. The more rapid growth of $B$. halophila on $\mathrm{NaCl}$ media over the range of temperatures reported here indicates that it is a true halophile, in agreement with the recent statement of Andrews \& Pitt (1987). Optimal growth occurred only in the presence of $\mathrm{NaCl}$ over the entire range of $a_{\mathrm{W}}$ values supporting growth. Under unf avourable conditions, i.e. at high $a_{\mathrm{W}}$ values and low temperatures, $B$. halophila may even have an obligate requirement for $\mathrm{NaCl}$. It was very sensitive to high concentrations of sugars.

$P$. pisce was reported by Andrews \& Pitt (1987) to exhibit superior growth below $0.90 a_{\mathrm{W}}$ on media containing $\mathrm{NaCl}$. It can also be reasonably described as a halophile. Remarkably, germination and growth of $P$. pisce occurred after $17 \mathrm{~d}$ on media containing saturated $\mathrm{NaCl}$ $\left(0.746 a_{\mathrm{w}}\right)$. The ability of Polypaecilum spores to germinate after such a long period on $\mathrm{NaCl}$ at a very low $a_{\mathrm{W}}$ indicates a special ability to survive in an environment destructive of the spores of most species.

For $P$. pisce at all temperatures studied, the $a_{\mathrm{W}}$ required for optimal growth was little affected by solute, but at low $a_{\mathrm{W}}$ radial growth rates were very much dependent upon solute; an important point when considering competition for colonization of a high-salt environment such as that encountered during drying of fish. The studies reported here indicate that $P$. pisce 
appears to be uniquely suited to colonizing partially dried salt fish, and this offers an explanation for its frequent occurrence on this commodity (Wheeler et al., 1986). B. halophila, although extremely salt tolerant, is much less likely to cause spoilage of drying or dried salt fish as its maximum growth rates are very low. The optimum growth temperature for both $B$. halophila and $P$. pisce was near $30^{\circ} \mathrm{C}$.

The establishment of the temperature-water relations of these fungi will aid work currently underway to revise the technology used to produce dried fish in tropical countries.

This project was supported by a grant from the Australian Centre for International Agricultural Research.

\section{REFERENCES}

ANDREws, S. \& PitT, J. I. (1987). Further studies on the water relations of xerophilic fungi, including some halophiles. Journal of General Microbiology 133, 233238.

NoRRISH, R. S. (1966). An equation for the activity coefficients and equilibrium relative humidities of water in confectionery syrups. Journal of Food Technology 1, 25-39.

PITT, J. I. (1975). Xerophilic fungi and the spoilage of foods of plant origin. In Water Relations of Foods, pp. 273-307. Edited by R. B. Duckworth. London: Academic Press.
PitT, J. I. \& Hocking, A. D. (1977). Influence of solute and hydrogen ion concentration on the water relations of some xerophilic fungi. Journal of General Microbiology 101, 35-40.

PitT, J. I. \& Hocking, A. D. (1985). New species of fungi from Indonesian dried fish. Mycotaxon 22, 197-208.

Robinson, R. A. \& Stokes, R. H. (1955). Electrolyte Solutions. New York: Academic Press.

Wheeler, K. A., Hocking, A. D., PItT, J. I. \& ANGGawati, A. M. (1986). Fungi associated with Indonesian dried fish. Food Microbiology 3, 351-357. 